\title{
Topografia dróg na Wyspie \\ Pielgrzymka duchowa w filmie Pawła Łungina
}

\author{
KATARZYNA KOLMAN
}

1

Gdzie jesteś ${ }^{1}$ - pyta Bóg Adama. W odpowiedzi pierwszy człowiek określa swoją egzystencjalną topografię po grzechu pierworodnym: w przestrachu, nagości i ukryciu. Dotychczas te dwie obecności - boska i ludzka - pozostawały ze sobą w relacji dialogicznej i w przestrzeni bezpośredniego obcowania, w której dzieliły tę samą tożsamość ontologiczną. Pytanie: Gdzie jesteś? zmusza Adama do ponownego zdefiniowania swojego miejsca i swojej kondycji w obliczu wyboru, jakiego dokonał. To pytanie jest jednocześnie pytaniem o aktualny moment jego bycia wobec Boga. Czy Bóg jest nadal punktem początkowym i docelowym drogi Adama? Czy strach, świadomość własnej nagości i przekonanie, że zdołał się schronić przed Bożym wzrokiem, nie mówią o radykalnym zwrocie w drodze, której continuum przerwał? Podejmując decyzję o zaprzestaniu wsłuchiwania się w słowo Boga i wpatrywaniu w Jego oblicze, zerwał dialog boskiego z ludzkim i przekierował go z boskiego „Ty” na ludzkie ,ja”. Ta zmiana kierunku wpłynęła równocześnie na reorientację $\mathrm{w}$ relacjach $\mathrm{z}$ Ewą, osobą najbliższą mu po Bogu w obrazie i podobieństwie, i na reorientację w relacji do stworzonego świata. Upadek spowodował zerwanie fundamentalnych dla Adama więzi porozumienia z Bogiem i drugim człowiekiem oraz wpłynął na rozumienie otaczającej go rzeczywistości ${ }^{2}$. To pierwotne umiejscowienie Adama naprzeciw Boga (a co za tym idzie - człowieka i świata) grzech zmienia w umiejscowienie przeciw Bogu. Obrana przez pierwszego człowieka droga odwrotu staje się drogą grzeszności. Od tej pory będzie musiał nieustannie zawracać z szerokich gościńców prowadzących donikąd na wąskie ścieżki prowadzące do pierwotnego punktu wyjścia.

Pytanie: Gdzie jesteś?, jest przede wszystkim pytaniem nie o miejsce człowieka rozumiane jako stały punkt jego po(bytu) w czasie, przestrzeni i w konkretnej rzeczywistości, ale o bieżące momentum w jego drodze do Boga. To pytanie postawione pierwszemu człowiekowi w kwestii jego ,,istotowego ukierunkowania”: czy „od” Boga czy „ku” Bogu? - a zarazem rozstrzygające o sensie ludzkiej egzystencji. Można w tym kontekście przyjąć, że człowiek istnieje na sposób sensowny, ponieważ jest w drodze realizującej się pomiędzy „od” a „ku”. Egzystencja, która zostaje uruchomiona $\mathrm{w}$ chwili narodzin i nieruchomieje w chwili śmierci, trwa w ruchu. Sprzeczność sformułowania ,trwanie w ruchu” (trwanie kojarzące się jednak z byciem w miejscu i ruch implikujący podążanie do przodu) łączy w sobie jakości jedynie pozornie przeciwstawne. Droga z punktu widzenia fizyki jest funkcją czasu, a więc nie ma trwania, wszystko pozostaje w ruchu. Z punktu widzenia metafizyki tę samą drogę przebywa się właśnie w miejscu trwania, gdzie trwanie staje się równocześnie ruchem. Paradoks drogi metafizycznej polega na tym, że 
jest drogą „w miejscu” - w tym jednym punkcie, w którym odpowiedź na pytanie „gdzie?” określa jej kierunek. To jeden decydujący punkt, kairos: czas krytyczny, decydujące znaczenie, szczególne wydarzenie, rozstrzygająca chwila, ale i stosowna pora, nadarzająca się okazja, sposobność ${ }^{3}$. Dla pierwszego człowieka sytuacja związana z popełnieniem grzechu pierworodnego miała cechy kairos w znaczeniu odnoszącym się do czasu. Upadek Adama, „wyłamanie się” z ruchu ku Bogu było czasem krytycznym, decydującą chwilą przesądzającą o jego dalszym losie naznaczonym znojem i trudem w doświadczaniu rzeczywistości oraz niezrozumieniem i bólem odrzucenia w doświadczeniu drugiego człowieka. Sytuacja wiążąca się z popełnieniem grzechu również dla wszystkich innych ludzi ma cechy kairos, jest jednak interpretowana jako nadarzająca się okazja do zmiany i sposobność powrotu do Boga w akcie pokuty przez zadośćuczynienie za popełnione zło. Kairos rozumiany jest w tym wypadku jako czas łaski i szczególnego Bożego działania przekraczającego ograniczony swoją materialną właściwością czas chronos.

\section{2}

Perspektywa refleksji teologicznej nad filmem Wyspa (2006) Pawła Łungina wynika z przyjętej przez reżysera narracji o życiu człowieka w jego odniesieniu do Boga. Punkty graniczne tego odniesienia: wina, pokuta i przebaczenie wprowadzają w tkankę dzieła filmowego rzeczywistość religijną. Główny bohater filmu, Anatolij, w odpowiedzi na pytanie „Gdzie jesteś?” wybiera drogę pokuty i pielgrzymki powrotnej do Boga realizowanej w duchu ascezy i ogołocenia. W tym kontekście Wyspa nie wpisuje się w klasyczny paradygmat kina drogi - na pewno nie w powszechnie przyjętym rozumieniu tego terminu, który zwykle jest kojarzony z bohaterami przemieszczającymi się fizycznie w znanym sobie bądź nieznanym kierunku, celowo lub bez celu, podróżującymi, uciekającymi, celebrującymi wolność, kontemplującymi życie upływające w drodze. Wyspa nie jest filmem drogi w tym najbardziej dosłownym znaczeniu. Jest filmem nie tyle o drodze rozgrywającej się w określonych warunkach czasowych i przestrzennych oraz noszącej W związku z tym znamiona fizycznego przemieszczania się, ile przede wszystkim o drodze wewnętrznej rozpiętej między doczesnością a wiecznością, o drodze „,poupadkowej”. Opowiada o wielości i wielokierunkowości dróg ludzkich w ogóle, o powrotach wpisanych na stałe w dialektykę drogi: do siebie, do drugiego człowieka, do Boga. Pokazuje historię ludzkiego dwutorowego podróżowania, historię jednej drogi, przebiegającej w codziennym znoju i trudzie, i tej drugiej, wznoszącej się z upadku ku Innemu, Tajemniczemu, Nieodgadnionemu. Równoległe sąsiedztwo dróg ustanawia właściwe miejsce przebywania człowieka. Cezary Wodziński pisze, że właściwym byciem wiersza jest bycie w drodze. To , wychodzenie z człowieczego", przekraczanie tego, co ludzkie, $i$ wkraczanie $w$,,region Niesamowitego" 4. A zatem wiersz to zapis doświadczenia przekroczenia przestrzeni oswojonej ludzką refleksją na rzecz przestrzeni niepodlegającej kategoriom deskryptywności znanej człowiekowi. Niesamowite pozostaje równocześnie Nienazwane. Nie może zostać zdefiniowane, ponieważ ze swojej natury znosi wszelkie określenia dostępne ludzkiemu językowi. A jednak wyłącznie w tym właśnie języku możliwe jest popełnienie „wykroczenia” - wyjście poza ustalone reguły komunikacji i zburzenie porządku logicznie postępującej narracji, aby otworzyć przed 
człowiekiem terytorium, ku któremu kieruje on swoje najgłębsze tęsknoty. Podobna sytuacja ma miejsce w modlitwie, rozumianej jako poezja wzajemności słowa ludzkiego i Bożego, w której człowiek doświadcza krzyżowania się ścieżek doczesnych i duchowych. To w słowie modlitwy wychodzi on poza granicę doczesności i wznosi duszę w „regiony Niesamowitego”. Wyspa jest również filmem o chodzeniu drogą modlitwy. Pokazuje życie Anatolija poddane całkowicie dynamice dia$\operatorname{logu} \mathrm{z}$ Bogiem, w którym sens realizuje się w semantyce wypowiadanych w modlitwie słów i związanych z nią gestów. To także obraz modlitwy traktowanej jako „miejsce zadomowienia” w świecie. W prostych słowach kierowanych do Boga w ewangelicznych przypowieściach, w anaforach i codziennych pobożnych praktykach Anatolij odnajduje swój dom.

\section{3}

Sekwencja otwarcia nakreśla zarówno dramaturgiczny kontekst sytuacyjny, jak i dramatyczny kontekst egzystencjalny głównego bohatera. Można ją potraktować w związku z tym jako symboliczną ekspozycję wprowadzającą w historię grzechu i pokuty, rozgrywającą się na tle surowej i chłodnej natury. Przestrzeń i czas będą tu mniej istotne niż opowiedziana historia człowieka pielgrzymującego po zbawienie. Sekwencja otwarcia inicjuje równocześnie tajemnicę. W planie ogólnym widać postać płynącą łodzią, następnie w zbliżeniu idące nogi i zaraz potem (po panoramie) ciało, które - zespolone i zjednoczone z ziemią - przylega do niej „krzyżem”. W tle słychać modlitwę. Nieznana jest tożsamość modlącego się. Tekst wypowiadanej modlitwy sugeruje, że ma ona charakter pokutny. Topografia miejsca również pozostaje niedookreślona. Wiadomo jedynie, że jest to przestrzeń odosobniona, którą odmawiający modlitwę wybrał celowo na miejsce swojej penitencji. W ujęciach w planie ogólnym zostaje zarysowana ,architektonika” rzeczywistości: kolorystyczna i strukturalna jednolitość świata przedstawionego z dominującymi zimnymi barwami, nagością przybrzeżnych skał, chropowatością ziemi i jednostajnie poruszającymi się falami. W zbliżeniach pokazane jest ciało ludzkie zatopione w całej swojej fizyczności w modlitwie skierowanej do Boga. To rzeczywistość wewnętrznego intymnego wyznania skruchy przechodzącego w błagalne wołanie o litość. Naprzemienność planów szerokich, oddających dynamikę życia zewnętrznego, i planów bliskich, pokazujących głównego bohatera podczas jego monologu z Bogiem i w dialogach z tymi, z którymi skrzyżuje się jego droga, będzie konsekwentnie utrzymana w całej narracji. W kolejnych obrazowych odsłonach, przebiegających w dialektyce oddalania i zbliżania, będzie się wyjawiać tajemnica tożsamości głównego bohatera i historia pokazująca, że początkiem świętości jest właściwa postawa wobec grzechu, ona zaś powoduje, że w życie człowieka wkracza Bóg ze swoja łaska jako lekarz dusz, w miejsce zamętu etycznego wprowadzający harmonię, $w$ miejsce metafizycznego rozdarcia-spójność, a w miejsce duchowego cierpienia spowodowanego wypaleniem przez grzech-przynosi ukojenie ${ }^{5}$.

Modlitwa odmawiana w pierwszej scenie filmu, tzw. modlitwa Jezusowa, polega na bezpośrednim zwróceniu się do Chrystusa słowami: Panie Jezu Chryste, zmiłuj się nade mna, grzesznym ${ }^{6}$. To jedno z najbardziej intymnych wezwań, jakie modlący się może skierować do Boga, prosząc o Jego ingerencję w ziemską, a więc z gruntu grzeszną kondycję wzywającego. Przywołując Bożą obecność - a tak wed- 
ług tradycji chrześcijaństwa zachodniego, jak i wschodniego dzieje się w momencie wypowiedzenia imienia Jezus - modlący się uznaje, że jego indywidualne istnienie jest całkowicie zależne od Boga. Warunkiem ludzkiej obecności jest obecność Boża. I tylko Bóg gestem nieskończonego miłosierdzia jest w stanie przywrócić człowiekowi zależność tego uwarunkowania. Modlitwa Jezusowa w tradycji prawosławia pozwala równocześnie utrzymać serce w nieustannej łączności z Jezusem i zrezygnować z własnej refleksji na rzecz kierowania myśli ku Bogu. Powoduje ona, że ten, który się modli w rytmie powtarzania tych samych słów, uczy się wyznaczać według nich rytm swojej codzienności. Przypominają mu one również o tym, że terytorium, po którym się porusza, nie jest jego własnością, a wszystko, co robi, powinien robić w całkowitym oddaniu się Bogu. Ciągłe przyzywanie w tej modlitwie jednego i świętego imienia jest stawaniem przed Bogiem i powierzaniem Mu się w każdym przeżywanym momencie życia. Nie jest ona przeznaczona na żadna konkretna porę dnia (...); może być odmawiana nieustannie. Jej krótka formuła pozwala skupić myśli łatwiej niż przy odmawianiu innych modlitw. Jest to jednocześnie modlitwa doskonała, ponieważ zawarte sa w niej odniesienia do podstawowych prawd wiary - wcielenia i Trójcy Świętej ${ }^{7}$. Wypowiadający modlitwę Jezusową ,zanurza” w ten sposób własne jestestwo w człowieczeństwie i bóstwie Jezusa, aby tym samym aktualizować w sobie nieustannie obie te natury.

Z praktyką modlitwy Jezusowej jest także związana praktyka pokłonów mająca charakter pokutny. Gest skłaniania głowy wyraża przede wszystkim pokorę. W głębokim pokłonie następuje symboliczny powrót do serca, jedynej i prawdziwie obecnej w człowieku rzeczywistości, kiedy głowa znajduje się w dole, a serce ponad głową. Ta symboliczna „degradacja” głowy w pokłonie oznacza rezygnację z przyznania prymatu racjonalnej refleksji nad naturą Boga i pokusą Jego antropomorfizacji. Odrzucenie ratio na rzecz esse przenosi całe skupienie na odczuwanie i doświadczanie obecności niezdeterminowane rozumowo czy wyobrażeniowo.

W modlitwie uczestniczy zintegrowana cielesność i duchowość człowieka. Kontakt z Bogiem „ma miejsce” w ciele, ponieważ ludzka cielesność jest dla Boga miejscem Jego uobecnienia się. Wszelkie poruszenia duchowe przekładają się na poruszenia cielesne. Anatolij pada krzyżem na ziemię w uznaniu własnej grzeszności i małości. Przywiera ciałem do prochu, z którego powstał. Wykonuje ruch przylgnięcia do ziemi konotujący całkowite ukorzenie się przed obliczem Boga.

Jesteśmy świadkami fragmentu pielgrzymki pokutnej Anatolija, który prosi o odpuszczenie grzechów. Pielgrzymuje do miejsca odludnego i staje przed Bogiem w prawdzie o swojej ludzkiej kondycji. Przeżywa „misterium odosobnienia”: odejścia od innych ludzi i od świata oraz wejścia w rzeczywistość przebywania z Bogiem, żeby uświęcić się w Jego obecności. Łacińskie sacrificare, oznaczające uświęcenie, to właśnie ,znalezienie się w oddzieleniu dla Boga”. Anatolij wiedziony wewnętrznym przynagleniem i ciążącymi mu grzechami szuka odludzia. Jego intuicja, bliska intuicji wielkich świętych i mistyków, podpowiada mu, że tylko przebywanie z Bogiem sam na sam jest drogą ocalenia.

\section{4}

Anatolij jest centralną postacią w filmie, a jego aktywność fizyczna i modlitewna wyznacza zarówno tempo opowiadanej historii, jak i kierunek ruchu - tego najbardziej podstawowego, fizycznego, realizującego się przede wszystkim w jego 
pracy, oraz tego unoszącego się ponad materią pokazywanej rzeczywistości w modlitwie, w rozmowach Anatolija z ojcami oraz w dialogach z osobami przychodzącymi do niego po pomoc. Pokazywana w szerokich planach pochylona sylwetka Anatolija pchającego taczkę, nieustannie pokonującego ten sam odcinek między składowiskiem węgla a kotłownią, oddaje monotonny rytm wykonywanego zajęcia. Trajektoria ruchu nie ulega zmianie: precyzyjne „tam” i „,z powrotem”. Cała rzeczywistość realizuje się w powolnym jednolitym rytmie pracy, która trwa nieprzerwanie, bez względu na zmieniające się pory dnia czy roku. Taczka Anatolija przesuwa się wciąż w tym samym tempie. Rytm natury nie współgra z rytmem pracy. W tej drodze nie ma przerw ani odpoczynku. Jest ona tak samo nieustanna, jak modlitwa odmawiana na przemian z wykonywaną pracą lub równocześnie $\mathrm{z}$ nią. W panoramach widzimy Anatolija płynącego łodzią w miejsce odosobnienia, kiedy zmienia na chwilę kierunek z wertykalnego na horyzontalny, żeby zanieść do Boga swoją modlitwę. Zmienia się równocześnie perspektywa jego patrzenia: wzrok skierowany ku ziemi podczas wożenia węgla wznosi się do góry podczas dziękczynienia i błagania. Obserwujemy pracującego i modlącego się człowieka, który przecina niezmienny pejzaż linia wyznaczona przez własna sylwetke, wykonując tę sama monotonna, ciężka prace (... ${ }^{8}$. Jej statyczny rytm jest przerywany dynamicznym rytmem spotkań z ludźmi przypływającymi na wyspę w poszukiwaniu rady i pomocy u „ojca” Anatolija oraz jego rozmowami z innymi mnichami. Interakcje z ludźmi pokazywane w półzbliżeniach i zbliżeniach nabierają większej ruchowej intensywności. W jednolicie „czysty” ruch pracy i modlitwy wdziera się ruch ludzkich emocji, wewnętrznych sprzeczności i nieuporządkowanych historii. Anatolij dopasowuje swoją dynamikę do tej nowej jakości ruchu, aby zaraz potem powrócić do właściwego sobie tempa.

W obrazie jest utrzymany rytm historii człowieka oddanego pracy i modlitwie - panoramy pracującego i modlącego się Anatolija są przerywane bliskim ujęciami spotkań z ludźmi. Powrót do rytmicznej równowagi odbywa się dzięki szerokim ujęciom topografii przestrzeni oraz zbliżeniom na detale przyrody. W mikroskali świata Anatolija i makroskali świata przedstawionego upływający czas nie ma znaczenia. Ten doczesny realizuje się w codziennych, żmudnych i powtarzalnych czynnościach. Czas wieczny trwa w niezmienności i stałości materia prima: kamieni, wody i ziemi. Obrazy pracy przechodzą w obrazy natury w kompletnym ,zatraceniu" czasu. Prostota życia i niewzruszoność przyrody korespondują z prostą formą obrazową filmu. Upływ czasu nabierze znaczenia dopiero po przyjeździe na wyspę Tichona, który wyznaczy kres ziemskiego pielgrzymowania Anatolija. Cała konstrukcja dramaturgiczna filmu jest temu podporządkowana: Anatolij pokutuje za popełniony grzech i czeka na przebaczenie. Do momentu uzyskania przebaczenia świat „wstrzymuje” dla Anatolija swój bieg.

W całym filmie kilkakrotnie w planie ogólnym jest pokazana wyspa ze znajdującym się na niej monastyrem i kotłownią oraz zaledwie kilka scen ukazujących topografię obu budynków. Kotłownia pozostaje w oddaleniu od świątyni, tak jak wyspa jest oddzielona wodą od stałego lądu. Anatolij nie mieszka z resztą mnichów i opuszcza wyspę, szukając odosobnienia dla swojej praktyki modlitewnej. Wyspa, odcięta od reszty świata, samym swoim położeniem sprawia wrażenia miejsca pustynnego. Jej „pustelniczy” charakter dookreślają obrazy surowej, nagiej natury. Ascetyczny pejzaż porozrzucanych w bezładzie skał, zmarzniętej ziemi i bezkres 
wody otaczającej wyspę korespondują z wewnętrznym pejzażem ogołocenia głównego bohatera. To ikonostas świata surowego i wyczyszczonego z przepychu barw - tak inny od bogactwa kolorystycznego i wizualnego charakterystycznych dla prawosławia. Patrzymy na jednostajnie monochromatyczny obraz rzeczywistości, w którym światło (lux mundi) emanuje jedynie z ikonostasu w świątyni i (paradoksalnie) z paleniska w kotłowni Anatolija. Jedna z podstawowych kategorii estetyki wschodniej - kategoria jasności, claritas, obecna w Bogu i odbijająca się w całym stworzeniu - jest pokazana w filmie jedynie w tych dwóch momentach. Światło ognia w kotłowni - ognia, który w Biblii oznacza przemianę i żywioł Bożego działania w duszy człowieka - oddaje procesy duchowe zachodzące we wnętrzu Anatolija. To claritas odbije się na jego twarzy w scenie rozmowy z ojcem Jowem, podczas której Anatolij będzie antycypował własną śmierć, oraz w jednej z ostatnich scen filmu, podczas spotkania z Tichonem. Twarz Anatolija oświetli blask ognia symbolizującego oczyszczenie z grzechów oraz gotowość do stanięcia przed Bożym obliczem.

Mimo że historia jest osadzona w religijnym kontekście prawosławia, reżyser rezygnuje z „nachalnego” symbolicznego wizualizowania. Buduje rzeczywistość skromną, realistyczną i wyczyszczoną z sakralnej stylistyki. Nie pokazuje realiów życia monastycznego, poza jedną sceną zbiorową liturgii w monastyrze i pojedynczymi scenami sytuacyjnymi, w których ojcowie Jow i Filaret objawiają się w swoich klasztornych rolach zarządcy i przełożonego.

Przestrzeń ma charakter eksterytorialny: wyspa z monastyrem jest wydzielonym miejscem świętym, gdzie ciąg wydarzeń jest poddany nie ludzkiej, a Bożej logice. Wiele klasztorów znajdowało się i znajduje na wyspach (...). Także bezimienny filmowy monastyr (...), co w naturalny sposób powodowało pewna izolację $i$ wycofanie się ze świata wstępujących tam osób ${ }^{9}$. Ale równocześnie ma też cechy ekstemporalności: upływający czas nie jest mierzony w swojej chronologii, a w wiecznym teraz, jedynej jednostce czasowej właściwej Bożej obecności. Eksterytorialność i ekstemporalność przestrzeni obrazowej są charakterystyczne dla pewnego rodzaju ikon. W tak zwanych ikonach z życiem, czyli przedstawienia ilustrujące życie są oddzielone od postaci centralnej i zawierają mniej lub bardziej precyzyjne wskazówki dotyczące czasu oraz przestrzeni, w których rozgrywają się ukazane wydarzenia ${ }^{10}$. Podobnie jest w Wyspie. Czasowy i przestrzenny wymiar w filmie, również przez sposób funkcjonowania Anatolija, nabiera cech „nadwymiaru". Ikona za pomoca swojej odwróconej perspektywy, swoich linii $i$ antynomicznych form, objawia strukturę duchowa tej samej rzeczywistości, jej schemat idealny, jej milczaca głębię ${ }^{11}$. Anatolij swoim postępowaniem, daleko odbiegającym od ogólnie przyjętych norm, zakłóca porządek rzeczywistości. Wprowadza destabilizację i odwraca perspektywę patrzenia na świat. Postrzega go jako przestrzeń zapośredniczenia między człowiekiem a Bogiem, jako tę najbardziej zewnętrzną, poznawalną na ludzki sposób tkankę rzeczywistości, która ma prowadzić do jej głębszego zrozumienia.

\section{5}

Scena z przeszłości daje wgląd w początek drogi głównego bohatera. Anatolij, palacz na okręcie podczas II wojny światowej, staje wobec najtrudniejszego dylematu moralnego: życie drugiego człowieka zostaje oddane w jego ręce. Ten drugi 
gotów jest bez wahania i strachu ponieść śmierć, nawet z ręki kolegi, a zwłaszcza w sytuacji, gdy niemieccy oprawcy dla zabawy zmuszają go do zabójstwa. Anatolij przerażony, błagając o własne życie, poddaje się i bezwolnie wykonuje rozkaz wroga, strzelając do swojego kapitana. Scenę, w której kapitan wpada do wody, a Anatolij cieszy się, że przeżył, kończy wybuch.

Scena z przeszłości jest utrzymana w innej stylistyce barwnej. Zmniejszone nasycenie koloru powoduje, że oglądamy czarno-biały film. Jednoznaczna tonacja obrazu pozostaje w kontraście do niejednoznacznej sytuacji bohatera i wyboru, którego musi on dokonać. Jedyny akcent kolorystyczny to czerwień flagi powiewającej na statku wroga. Dynamiczny montaż następujących po sobie ujęć wzmaga napięcie. Akcja toczy się wartko aż do tragicznego finału. Ten szybki rytm współgra $\mathrm{z}$ intensywnością przeżyć bohatera. Tempo opowiadania $\mathrm{w}$ tej scenie kontrastuje z tempem wprowadzonym w sekwencji otwarcia. Kiedy nieprzytomnego Anatolija odnajdują na plaży mnisi z monastyru na wyspie, powraca tempo ze sceny otwarcia: nieśpieszne i kontemplacyjne. Wiemy, że wyspa znajduje się w pobliżu miejsca popełnionej zbrodni, gdzie Anatolij doświadczył najbardziej dramatycznego upadku, ale gdzie również dozna odkupienia. Uratowany, pozostaje na wyspie, ale nie wiemy, czy był to jego świadomy wybór, zrządzenie ślepego losu czy akt Bożej woli. Anatolij wyrusza w drogę, podobnie jak starotestamentalny prorok, tytułowy bohater Księgi Jonasza, która w Biblii jest nazywana „księgą drogi”. Został on wysłany w drogę przez Jahwe, wbrew swoim intencjom i oczekiwaniom. W konsekwencji wypełnił zleconą mu przez Boga misję, której początkowo nie chciał podjąć. Żyjąc egoistycznie i patrząc obojętnie na ludzi wokół siebie, dbał głównie o własną wygodę. I w tym miejscu zamierzał pozostać. Bóg trzykrotnie wzywa go do powstania i nakazuje mu opuścić to miejsce. Jonasz trzykrotnie odmawia, uciekając i chowając się przed Bogiem. Ta trzykrotna odmowa znajduje zresztą odzwierciedlenie w hebrajskiej transkrypcji jego imienia. Ostatecznie nie udaje mu się uciec przed Bogiem i rusza w drogę, do której jest przez Niego zaproszony. Idzie do Niniwy i nawołuje jej mieszkańców do pokuty, po to by mogła ich dotknąć ręka Bożego miłosierdzia. Jak każda historia biblijna, tak i ta o Jonaszu jest historią przemiany duchowej, w której chodzi o rozpoczęcie świadomego, odpowiedzialnego - względem Boga i innych - oraz dojrzałego życia religijnego. Jonasz, który chciał uciec przez Bogiem i ukrywał się przed Nim, nie przewidział, że Bogu chodzi bardziej o podjęcie przez niego tej wewnętrznej pielgrzymki niż stanięcie przed królem Niniwy. Paweł Śpiewak pisze, że nie wiemy, czytając Księgę, czy sam Jonasz dojrzat do intensywności życia religijnego. Na pewno idzie o to, żeby uważny czytelnik zobaczyl dramat duchowy $i$ zyciowy Jonasza, a w nim samego siebie. Jonasz uciekat przed Bogiem. A czy można przed Nim uciec? Czy jest miejsce, w którym możemy się przed Nim skryć? ${ }^{12}$

\section{6}

Anatolij nie ukrywa się przed Bogiem. Przeciwnie, szuka ścieżek dotarcia do Niego w duchu formuły ora et labora, która streszcza dynamikę życia zakonnego. Trasa pokuty Anatolija realizuje się między kotłownią a składem węgla, jego domowym ołtarzem a ikonostasem w monastyrze $\mathrm{i}$ we wszystkich błagalnych inwokacjach modlitewnych. Ten ostatni odcinek trasy nadaje jej najgłębszy sens ${ }^{13}$. Brzemię ciężkiej pracy w prochu ziemi, którym został obarczony pierwszy czło- 
wiek wypędzony z raju, realizuje się w jego przypadku dosłownie. Anatolij wykonuje ciężkie, monotonne i niewdzięczne zajęcie - kruszy bryły węgla i przewozi je taczką do kotłowni. Obraz Anatolija rozłupującego węgiel i pchającego po pomoście taczkę powraca na zasadzie refrenu. Przez powtarzalność porównanie z pracą Syzyfa nasuwa się samo - z tą jednak różnicą, że Syzyf wykonywał swoje zadanie w ramach kary, a Anatolij swoje w ramach pokuty. Śpi na węglu w kotłowni, nie dba o ubranie i pożywienie, nie gromadzi dóbr materialnych. Zaproszony do zamieszkania w monastyrze z ojcem Filaretem, odmawia. Chce zostać w miejscu swojego ogołocenia. Świątynia na wyspie, mimo że pozostaje ważnym punktem na mapie jego pielgrzymki, nie jest jej celem. Podczas liturgii zwraca się, wbrew regule, w inną stronę niż reszta modlących się ojców. Skorygowany, ponownie odwraca się w „swoim” kierunku - tym, który Chrystus Pantokrator wskazuje palcem na obrazku umieszczonym w jego domowym ikonostasie. W kadrze widać niewielki ołtarz z wizerunkiem Chrystusa, przed którym Anatolij pali świeczkę. Obraz Boga i obraz modlącego się do Niego człowieka zostają oddane w jednym ujęciu. Pomiędzy twarzą Anatolija a twarzą Chrystusa jest jedynie przestrzeń modlitewnej bliskości.

Pokłony wykonywane przez Anatolija przed domowym ołtarzem łączą symbolicznie przestrzeń ziemi (dołu) z przestrzenią nieba (góry) w jeden wymiar w ciele ludzkim. Również znak krzyża, w którym trzy palce skierowane do góry symbolizują Trójcę Świętą, a dwa do dołu - człowieczą i boską naturę Jezusa, jest znakiem hipostazy boskiego z ludzkim. Anatolij poddaje swoje ciało surowej ascezie, która ma je wyzwolić z uwikłania w cielesność otaczającego go świata wyrażającą się w pożądaniach, przywiązaniach i potrzebach materialnych. Ma także pomóc w zjednoczeniu z Bogiem. To, co pozostaje w jego ludzkiej jurysdykcji, zmienia siłą woli i konsekwentnym działaniem. Ale zjednoczenie z Bogiem wymaga również zmiany serca i ducha, a ta jest możliwa jedynie mocą działania Bożej łaski.

Stwórz mi, o Boże, czyste serce i ożyw mnie nowym i nieugiętym duchem! ${ }^{14}$ woła Anatolij, zwracając się do Boga słowami psalmu pokutnego. Autorstwo Psalmu 51 przypisuje się królowi Dawidowi. Miał się nim modlić do Boga po popełnieniu grzechu z Batszebą. Psalm opisuje poszczególne etapy pokuty, które stały się osobistym doświadczeniem Dawida. W pierwszej części pokutujący nazywa swój grzech i uznaje popełnione przez siebie zło. Staje przed Bogiem w świadomości pogwałcenia łączącej go z Nim więzi (wątek stawania przed Bożym obliczem często powraca w psalmach). Spojrzenie Boga jest dla człowieka konstytuujące. Odwrócone od grzesznika Boże oczy to najgorszy wymiar kary, ponieważ życie ludzkie uzyskuje potwierdzenie jedynie we wszechogarniającym wzroku Boga. W drugiej części psalmu pokutujący błaga o litość i Boże zmiłowanie. Oczyszczenie z grzechów jest możliwe jedynie wtedy, kiedy Bóg okaże mu swoje miłosierdzie. W części trzeciej pokutujący nazywa od nowa rzeczywistość, która stanie się jego udziałem po uzyskaniu przebaczenia. Oczyszczony przez Boga Dawid chce nawracać grzeszników i opowiadać innym o Bogu. Nie bez znaczenia jest fakt, że prośba Dawida dotyczy uwolnienia z winy za przelaną krew ${ }^{15}$. Anatolij w swoich modlitwach zwraca się również do Tichona, którego, jak sądzi, zabił. Nazywa go swoją ostatnią nadzieją i modli się o spokój jego duszy.

Psalm 51 poza tym, że jest psalmem pokuty i pieśnią lamentacyjną grzesznika konfrontującego się ze swoim przewinieniem, opisuje również specyfikę drogi du- 
chowej każdego człowieka. Pokazuje następujące po sobie etapy zbliżenia człowieka jako stworzenia do Boga jako Stworzyciela. Prośba o stworzenie czystego serca jest wołaniem o wejście w całkowitą zależność z Tym, w którego mocy leży danie człowiekowi nowego życia. Przestrzeń serca jest jedną z najważniejszych sfer duchowych w prawosławiu. To najbardziej intymna i niedostępna dla innego przestrzeń spotkania z Innym. Tu współobecność Boga i człowieka realizuje się bez pośrednictwa świata czy drugiego człowieka. Zniesione zostają dualizmy i kontradykcje charakterystyczne dla namacalnej rzeczywistości. W sercu człowieczeństwo osiąga istotową pełnię - uświęcenie. W Drodze człowieka inspirowanej nauczaniem chasydów Martin Buber zaproponował ścieżkę prowadzącą do świętości, którą może podjąć każdy człowiek właśnie w sercu. Nie musi zmieniać swojego położenia ani okoliczności. Powinien wsłuchać się w swój wewnętrzny głos najbardziej dojmującego pragnienia i zacząć je realizować. Drogę rozpoczyna zrozumienie siebie i poznanie swoich najgłębszych motywacji. Następnie należy się od siebie odwrócić i skierować w stronę świata - wyjść naprzeciw innym po to, żeby „się rozdać”. Wówczas na pewno dojdzie się do Boga, ponieważ Bóg będzie obecny wszędzie tam, gdzie człowiek podejmie swoje rozdawnicze działanie ${ }^{16}$. Obie wykładnie - i prawosławna, i chasydzka - wskazują na immanencję Boga we własnym wnętrzu i w drugim człowieku oraz w świecie.

\section{7}

Wszystko, co robi Anatolij, jest nieustannym składaniem ofiary z własnego życia. Oddaje je Bogu i ludziom. Nie zdaje sobie sprawy, że wchodzi tym samym na drogę świętości, co wybrzmi w rozmowie z ojcem Filaretem w dalszej części filmu. Konsekwentnie realizowana przez Anatolija codzienność pokuty w pracy i modlitwie, zwyczajne i powtarzalne, pozornie niewiele znaczące czynności wykonywane w duchu ascezy prowadzą go do zintegrowania cielesności i duchowości w drodze do uświęcenia. Największym pragnieniem Anatolija jest odpokutowanie za popełnione przewinienia. Ciężar grzechu staje się imperatywem dla wszystkich jego działań. Bóg, którego nie widzi, ale którego obdarza bezgranicznym zaufaniem, i człowiek, którego widzi i w którym dostrzega znaną sobie grzeszność oraz brak zaufania, ukierunkowują trasę jego pielgrzymki. Cały sens istnienia sprowadza się u Anatolija do przezwyciężania egoizmu i zapomnienia o sobie. Żyje on w stanie permanentnego umniejszania się i dawania coraz większej przestrzeni Bogu. To On jest tym, który ma całkowicie wypełnić jego rzeczywistość, a Anatolij tym, który jest capax Dei, „otwartym na Boga”. Otwartość na Boga jest wrodzoną dyspozycją do odnoszenia swojego istnienia do Tajemnicy, Pełni i Nieskończoności, które istnienie to przekraczają. To działanie podobne do tego, które Christopher Grabowski w pracy na temat Dekalogu (1998) Krzysztofa Kieślowskiego nazywa autotranscendencją. Bóg, przed którym człowiek jest odpowiedzialny, odsyła go na spotkanie z bliźnim. W tym spotkaniu człowiek odnajduje cel swojej egzystencji i przerasta samego siebie ${ }^{17}$. Musi wyjść poza swoją egocentryczną naturę, żeby spotkanie było w ogóle możliwe. Tutaj bezpośrednim punktem odniesienia jest drugi człowiek i świadomość jego obecności determinującej sens życia. W tym spotkaniu zmienia się sytuacja egzystencjalna jego uczestników. „Otwartość na Boga" jest również zdolnością do spotkania z Nim - spotkania totalnego, transformacyjnego dla całego ludzkiego bytu, w którym zmienia się sytuacja ontologiczna 
uczestniczącego. Dlatego codzienna zdolność do rezygnowania z siebie na rzecz przyrastającej w człowieku Bożej obecności, zaparcia się siebie $i$ uwierzenia słowu ${ }^{18}$, jest kluczowa w procesie nawrócenia.

\section{8}

Nie mamy wglądu w to, jak doszło do metanoi (z greckiego: przemiana /meta/ umysłu /nous/, ale również: zawracanie) Anatolija. W scenie z przeszłości widzimy człowieka niezdolnego do poniesienia ofiary, tchórzliwego, chcącego ocalić własne życie kosztem życia drugiego. W pozostałych scenach śledzimy rezultat radykalnej przemiany duchowej Anatolija. W filmie metanoja jest udziałem nie tylko Anatolija, podlegają jej także ojcowie Filaret i Jow. Każdy z nich przechodzi indywidualną przemianę, którą w ich wypadku można interpretować jako odnowę duchową na ścieżce powołania monastycznego. Jeśli chodzi o Anatolija, jest to zdecydowany zwrot umystu ku Chrystusowi ${ }^{19}$ i całkowita transgresja bytu przejawiająca się w jego oczyszczeniu (pokuta), nawróceniu duchowym (asceza i modlitwa) i upodobnieniu do Chrystusa (postawa wobec Boga i innych). Anatolij nie rości sobie praw do własnego życia, poddając je woli Boga. Chęć przeżycia, o którą tak bardzo zabiegał, przeradza się w pokorną służbę Bogu i bliźniemu. Ostatecznym celem metanoi jest więc uświęcenie: wejście w rzeczywistość transcendencji, w której horyzontalna droga człowieka zbiega się z wertykalną drogą Boską. To stan pełnej dojrzałości duchowej umożliwiający poniesienie bezinteresownej ofiary, żertwy w terminologii Tischnerowskiej ${ }^{20}$, z samego siebie. Wydaje się, że Anatolij nie do końca wierzy, że świętość jest jego udziałem. Dlaczego akurat przeze mnie Pan okazuje swoją łaskę? Wydaje się, że za moje grzechy udusić mnie to za mało. Zrobili tu ze mnie świętego. Jaki tam za mnie święty. Nie mam spokoju w duszymówi Anatolij do ojca Filareta. Filaret płacze. Inni widzą w nim kogoś odrębnego i wyobcowanego z naturalnego porządku rzeczy, kto ich zarówno przyciąga, jak i irytuje, ale obok kogo nie mogą przejść obojętnie. Dlatego wszystkie drogi na wyspie - i te duchowe, i te fizyczne - prowadzą do Anatolija.

Ojciec Jow wita Anatolija bożym pozdrowieniem mającym połączyć obu więzią w duchu braterskiej miłości. Anatolij wykorzystuje sytuację do uświadomienia mu jego grzeszności. Nie odnosi się do niej wprost. Nawiązuje do przypowieści z Księgi Rodzaju o Kainie i Ablu. Zazdrosny Kain zabija brata, ponieważ ofiara złożona przez Abla bardziej spodobała się Bogu. Jow jest zazdrosny o Anatolija, o sposób, w jaki Bóg działa w jego życiu i przez niego, o jego ofiarę wynagradzaną przez Boga łaskami, na które Anatolij w oczach Jowa nie zasłużył. Oczytany, mądry mnich, skrupulatnie przestrzegający reguł i dopełniający wszystkich obowiązków, nie rozumie, dlaczego jego przykładnie prowadzone życie zakonne nie znajduje aprobaty w oczach Boga. Wszystkie starania Jowa, adekwatność jego zachowań i właściwe praktykowanie wiary zostają zestawione z dezynwolturą Anatolija. Kluczowe dla jego drogi duchowej pytanie, które zadaje Anatolij [dlaczego Kain zabił Abla?], odbiera jako drwinę ${ }^{21}$. Anatolij nie drwi. Stara się sprowokować u Jowa refleksję na temat jego kondycji duchowej. Tak istotna dla ojca zarządzającego wiedza, którą czerpie z mądrych ksiąg, i władza, którą sprawuje w monastyrze, przesłaniają mu istotę powołania. Swoimi staraniami chce zasłużyć na Bożą łaskę, „kupić” coś, co każdy otrzymuje za darmo według hojnej ekonomii rozdającego. Jow jest przekonany, że Bóg nie chce przyjąć jego ofiary. Rozczarowany Bożym 


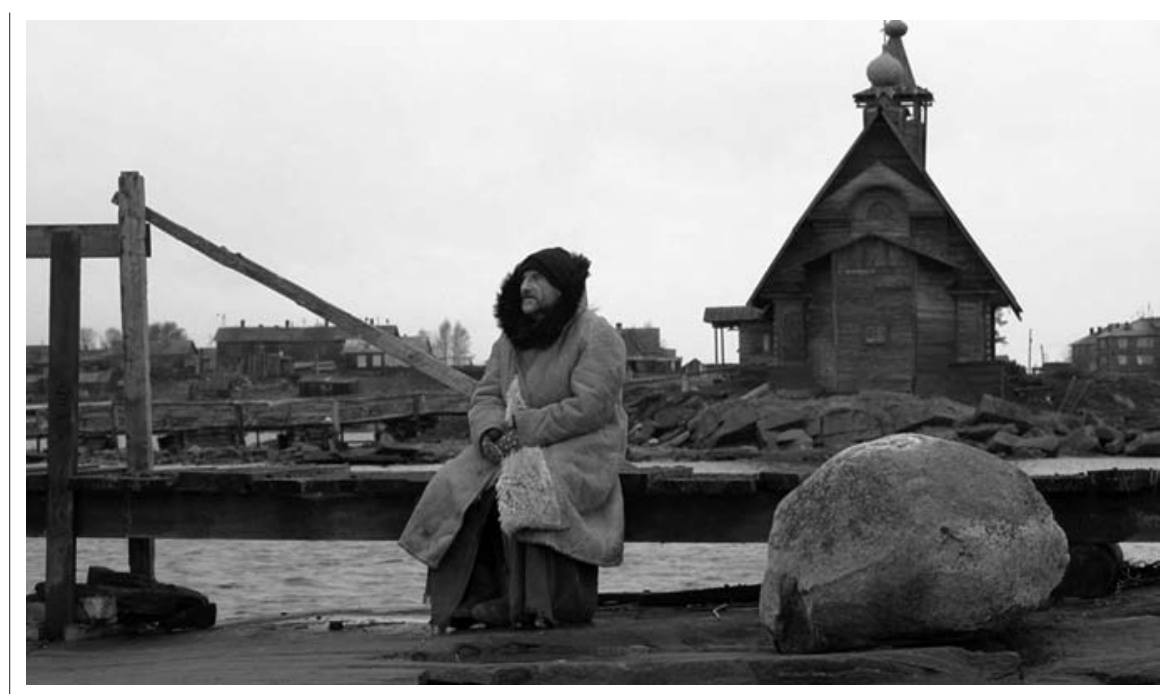

działaniem nie dostrzega, że życie człowieka powinno stanowić ciągłą próbę bycia bezinteresownym wobec Boga ${ }^{22}$. Postawa Anatolija, spontaniczna i nieograniczona żadnymi restrykcjami, jest w jego sposobie pojmowania rzeczywistości duchowej nie do zaakceptowania. Dodatkowo Anatolij uniża się przed nim, prosząc go o wybaczenie za nieświadomie popełnione zło i odwołując się do braterskiej miłości. Jow nie wie, za co ma kochać Anatolija. Niemożność bycia bezinteresownym wobec Boga przekłada się na jego relacje z ludźmi. Na miłość, zdaniem ojca Jowa, trzeba sobie zasłużyć. Anatolij próbuje mu pokazać jego interesowną, a przez to zniewalającą mentalność. Historia Kaina i Abla jak w soczewce skupia życie Jowa, które jest niewolniczym życiem zasługiwania na coś. Jow pomija w nim najważniejszą dla więzi z Bogiem wolność dziecka Bożego przejawiającą się w wewnętrznej dyspozycji serca. W konsekwencji, pod wpływem Anatolija, przechodzi przemianę. Zadaje mu kluczowe pytanie o sens życia w sytuacji dla Anatolija granicznej, kiedy ten przygotowuje się do śmierci. Konfrontacja ze śmiercią człowieka, z którego postępowaniem Jow tak zdecydowanie się nie zgadzał, każe mu inaczej spojrzeć na własną egzystencję. Widzi kogoś, kto nie boi się umrzeć, a jedyne, czego się boi, to stanąć przed obliczem Boga z powodu własnej grzeszności. Otwierając skrzynię, w której chce być pochowany Anatolij, Jow znajdzie w niej sieci rybackie. Przypomni sobie ich wcześniejszy dialog, w którym Anatolij powiedział: Obmyly mnie fale śmierci i sieci śmierci mnie pokryły. Jow zda sobie sprawę, że bliskość, w jakiej Anatolij pozostawał z Bogiem, pozwoliła mu na pokonanie lęku przed umieraniem.

Ojciec Jow przebywa najdłuższą z duchowych dróg - od pysznego przywiązania do nieomylności swoich przekonań po pokorne ukorzenie się przed „współbratem", który całe swoje życie zawierzył Bogu. Doświadcza miłości bliźniego. Będzie świadkiem i współuczestnikiem umierania Anatolija i będzie mu również towarzyszył w jego ostatniej drodze. W sekwencji zamknięcia Jow dźwiga na swoich plecach olbrzymi krzyż, pod którego ciężarem się ugina. Skojarzenie z drogą krzyżową nasuwa się samo. Ale może to być jednocześnie obraz niesienia krzyża własnego życia radykalnie odmienionego śmiercią Anatolija. 
Inna jest droga Filareta. W przeciwieństwa do ojca Jowa patrzy na „wybryki” Anatolija z dużą pobłażliwością i wydaje się, że rozumie naturę jego zmagań duchowych. Zdaje sobie sprawę, że zjednoczenie z Bogiem dokonuje się w głębi doświadczenia wewnętrznego, do którego otoczenie nie ma dostępu. Sam chciał wejść na drogę życia eremickiego, która umożliwiłaby mu pełne zespolenie z Absolutem. To ciązenie ,jednego ku Jedynemu” to prymat anachorezy, wyższość eremityzmu nad forma zakonna, arystokracja ducha, który uwalnia od wszystkiego, nawet od wspólnoty $i$ jej regut ${ }^{23}$. Funkcjonowanie Anatolija poza wspólnotą i jego niechęć do przestrzegania zasad ją obwiązujących są bliskie Filaretowi. W konsekwencji Filaret nie podjął drogi pustelniczej. Konfrontacja z Anatolijem przynosi po części wyjaśnienie, dlaczego tak się stało. Raport ojca Jowa na temat niesubordynacji Anatolija wymusza interwencję ojca Filareta. Ten próbuje przeprowadzić z Anatolijem rozmowę, która przeradza się w dialog teologiczny, ponieważ Anatolij na wszystkie pytania odpowiada cytatami z Biblii. Jest w jego odpowiedziach pewna doza przekory i gry z przełożonym, ale też przekonanie, że w słowie Bożym postępowanie, z którego powinien się wytłumaczyć, zostaje usprawiedliwione. Spotkania Anatolija z Filaretem przebiegają w dynamice dyskursu soteriologicznego i dotyczą grzeszności, cnót, zbawienia i życia wiecznego. W przeciwieństwie do scen z udziałem Anatolija i ojca Jowa, sfilmowanych w klasycznym ustawieniu plan - kontrplan, w scenach rozmów Anatolija i Filareta obaj są widoczni w kadrze, siedzą obok siebie i patrzą przed siebie. Takie ustawienie nawiązuje do przedstawienia ikonicznego. W centrum ikony, która jest obrazem, ale nie w zachodnim rozumieniu ilustracyjnym czy portretowym, znajduje się święta postać odzwierciedlająca Boże oblicze. Nie stanowi ono odbicia cech zewnętrznych, ale ma reprezentować idee zakorzenione w boskiej rzeczywistości. Anatolij i Filaret, dialogujący na temat Boga i jego działania w świecie, toczą rozmowę o swoim osobistym doświadczeniu zmagania się ze słabościami i doświadczaniu Bożej interwencji. Filaretowi właściwy jest głęboki namysł nad naturą Boga i Jego przymiotami, o ile w ogóle daje się On ,przymiotnikowo” zdefiniować. Największą wiarę Filaret pokłada w nieograniczonym Bożym miłosierdziu, mówiąc, że nie ma takiego grzechu, którego Bóg nie byłby w stanie wybaczyć. To odpowiedź na wątpliwości Anatolija udręczonego świadomością wielkiej grzeszności. Filaret widzi w nim człowieka, którego droga pokutna doprowadziła do poznania prawdy o swojej naturze, a przez to - w szerszej perspektywie - o naturze ludzkiej jako takiej. Anatolij mówi, że jego cnoty nic nie znaczą przed Bogiem, że śmierdzą. Filaret wie, że takim stwierdzeniem Anatolij wyraził faktyczny stan swojego wnętrza, pełnego pokory i przekonania o znikomości jakichkolwiek ludzkich zasług wobec Boga. Dobrze, że czujesz. Dzięki temu się zbawisz - odpowiada Filaret.

Obcujący z ikonami przeor monastyru również musi pozostawać w bliskim kontakcie z Bogiem umożliwiającym mu pisanie ikon. To droga nieustannego rozwoju duchowego i przekraczania swojej egoistycznej natury na rzecz tworzenia szczególnych Bożych wizerunków. Naturalne wydaje się w tym kontekście przywołanie postaci innego mnicha piszącego ikony, tytułowego bohatera $\mathrm{z}$ filmu Andrieja Tarkowskiego Andriej Rublow (1966). Pielgrzymujący Rublow zostaje ikonopisem dopiero wtedy, kiedy godzi się z tragizmem otaczającej go rzeczywistości i otwiera na tajemnicę ludzkiej egzystencji, którą jest miłość Boga. Dojrzewa wówczas jako człowiek i artysta. 
Sam proces tworzenia ikony jest w tradycji chrześcijaństwa wschodniego modlitwą. Ikonopis wchodzi w bezpośredni związek z Bogiem, który jest dla niego źródłem natchnienia i objawienia. Ikona nie powstaje w wyniku jego inwencji twórczej. Tworzącego ikonę uważa się za sługę Kościoła, który łączy Boga z człowiekiem. Sama ikona staje się zaś uprzywilejowanym miejscem ich spotkania. Nie tylko jest przedmiotem kontemplacji, ale równocześnie zakłada aktywne uczestnictwo modlącego się, który pr ze z nią wchodzi w kontakt z wiecznością. Zadaniem ikony jest wewnętrzna przemiana człowieka. Dla Filareta Anatolij jest żywą ikoną (zresztą koresponduje to z nauką ojców Kościoła Wschodniego, według której każdy człowiek powinien stać się „,ikoną Boga” przez naśladowanie Jego natury), dzięki której przejdzie duchową przemianę. W wyniku pożaru w monastyrze Filaret przenosi się do kotłowni Anatolija z zamiarem wspólnego modlenia się, rozmyślania o Bogu i życiu wiecznym. Chce się zbawić wspólnie z Anatolijem. W jakimś sensie jest to dla niego powrót do idei życia pustelniczego. Nie może jednak wyjść na pustynię w wygodnych butach, przykryty miękką kołdrą, z ułożonym według siebie schematem zbawienia. Pustynia, miejsce całkowitego ogołocenia, wymaga porzucenia swoich materialnych i duchowych przywiązań. Anatolij urządza Filaretowi seans „ganiania biesów” w kotłowni, którą zmienia w przysłowiowe piekło, żeby pokazać przełożonemu stan jego ducha. Dzięki niemu Filaret zdaje sobie sprawę ze swojej małej wiary wywołującej w nim lęk przed śmiercią oraz $\mathrm{z}$ upodobania do przedmiotów, które mają mu zapewnić komfort życia. Przez chwilę Filaret żyje życiem Anatolija. W długim ujęciu widzimy przełożonego monastyru zgiętego nad taczką wypełnioną węglem, a obok wyprostowanego palacza. Zaraz potem w zbliżeniu oglądamy ubrudzoną sadzą twarz Filareta upodobnioną do twarzy Anatolija. Ta zamiana ról staje się dla przełożonego monastyru niekonwencjonalną lekcją pokory. Widzi swoje oddalenie od Boga spowodowane pokładaniem zaufania w materialnej rzeczywistości i własnych przekonaniach. Anatolij uwalnia Filareta, pokazując, jak w ekstremalnej sytuacji jego lęk bierze górę nad ufnością. Znajduje również odpowiednią drogę dotarcia do serca zarówno ojca Jowa, jak i ojca Filareta. Udaje mu się obnażyć prawdziwe motywacje stojące za ich działaniami i w ten sposób zbliżyć obu do Boga. W końcu jest to towarzyszące wszystkim trzem dążenie i ostateczny cel ich doczesnej drogi. Scenę, w której ojciec Jow przychodzi do Filareta z „doniesieniem” na Anatolija, kończy modlitwa Filareta przed ikonostasem. Kamera przechodzi od modlącego się Filareta, przez modlącego się Jowa, do modlącego się Anatolija. W jednej sekwencji obrazowej zostaje uchwycone ich wspólne, ale jednocześnie bardzo indywidualne trwanie w modlitwie przed Bogiem.

\section{9}

W przeciwieństwie do proroka Jonasza, który został posłany do Niniwy, żeby nakłonić jej mieszkańców do pokuty i nawrócenia, tutaj grzeszna Niniwa w postaci przypływających na wyspę ,„pielgrzymów” przychodzi do Anatolija. Odwiedzający go szukają ulgi i pocieszenia w swojej bieżącej sytuacji, ale on dostrzega ich interesowność i postępowanie motywowane egoistycznym lękiem o samych siebie i zabiegami o dobra materialne czy komfort emocjonalny. Mimo tego staje po ich stronie, ponieważ ich słabości i niezdolność do poniesienia ofiary są mu bliskie. Dziewczyna w ciąży przychodzi po „błogosławieństwo” dla jej usu- 
nięcia, obawiając się samotnego życia i samotnego macierzyństwa. Dopiero Anatolij uświadamia jej, że dziecko będzie darem od Boga. Tam, gdzie wcześniej widziała śmierć, mądry starzec wprowadza życie. Inna kobieta, której mąż umiera gdzieś za granicą, a którego, jak podkreśla, darzy głębokim uczuciem, nie chce zostawić swojego gospodarstwa i wyruszyć w podróż. Stan posiadania gwarantujący stabilność i spokój jest dla niej ważniejszy od wyjazdu do nieznanego kraju i pożegnania męża. Prosi Anatolija o modlitwę za zmarłego, który de facto żyje. Obie ,grzęzną” w rzeczywistości dóbr doczesnych. W interwencji Anatolija szukają szybkich rozwiązań, nie rozumiejąc istoty prawdziwego poświęcenia. Ten pokazuje im, że egocentryczna monologiczność może zostać przekształcona w życiodajną dialogiczność, jeżeli spojrzą na swoje położenie jak na błogosławieństwo, a nie jak na przekleństwo. Miejsce ich nieszczęścia może stać się początkiem drogi zbawienia. W każdej z tych sytuacji Anatolij dopuszcza się pewnej „błazeńskiej” inwazji. Wkracza w ich rzeczywistość jako „Boży szaleniec”, burzy ją i ośmiesza, żeby pokazać, na jak kruchych podstawach została zbudowana. „Inność” Anatolija jest wyrazem ,inności” Boga działającego na przekór ich oczekiwaniom. Krzyczy na ciężarną dziewczynę, przepowiada jej samotne życie, którego ta się obawia, ale zapowiada narodziny syna, który będzie dla niej ocaleniem. Następnie wygania ją z wyspy. Ukrywa swoją tożsamość przed kobietą proszącą o modlitwę w intencji zmarłego męża, udając pomocnika świętego starca. Każe jej stanąć przy drzwiach i przysłuchiwać się ,ich” rozmowie. Prowadzi ją jednak z samym sobą, zmieniając intonację głosu. Z symulowanej rozmowy wynika, że mąż nie umarł, a ona powinna porzucić swoje dotychczasowe życie i jechać do niego. W tych scenach Anatolij pozostaje w permanentnym ruchu. Ani na chwilę nie wychodzi z narzuconego sobie rytmu pracy, mimo że zostaje on zakłócony zewnętrznym rytmem odwiedzających go kobiet. Kamera jest przy twarzach postaci pokazywanych blisko siebie. To obraz ludzkiego zmagania się wypełniony sprzecznymi emocjami i zawiedzionymi oczekiwaniami.

Na wyspę przypływa w końcu matka chorego chłopca, żeby prosić Anatolija o uzdrowienie go. Ta scena jest skomponowana inaczej niż poprzednie, z udziałem ciężarnej kobiety i rzekomej wdowy. W tamtych Anatolij odsłonił się jako widzący i wiedzący więcej. „Błazeńskim” sposobem dał obu kobietom głębszy wgląd w koleje ich życia. W scenie z chorym chłopcem Anatolij pozostaje w głębokim skupieniu modlitewnym. Staje wyprostowany przed Bogiem, prosząc Go o łaskę uzdrowienia z choroby. Odwołuje się do wiary matki i dziecka, ponieważ tylko głębokie zaufanie Bożej wszechmocy może spowodować, że „,zepsuta” materia zostanie naprawiona. Podczas modlitwy zmienia się wyraz jego twarzy. Anatolij opuszcza fizyczną przestrzenność i czasowość. Całym swoim jestestwem wchodzi w dialog błagalny z Bogiem. Podczas wykonywania głębokiego pokłonu postać znika z ekranu. Zostaje pusty kadr. Nie jego obecność jest tutaj najważniejsza, a Tego, który może zdziałać cud. I cud się wydarza. Chłopiec zostaje wyleczony. Anatolij wie, że za dar uzdrowienia obdarowany powinien podziękować Bogu przez udział we Mszy świętej i przyjęcie komunii, gdyż w przeciwnym razie dar zostanie odebrany ${ }^{24}$. Nakazuje matce zostać i wziąć udział w liturgii w podziękowaniu za uzdrowienie. Kobieta wykręca się terminowym ukończeniem projektu, przedkładając pracę nad dobro dziecka. Anatolij siłą zabiera chłopca z łodzi, tłumaczy matce, że w jej biurze była awaria, wszystko zalała woda, a pracownicy 
zostali zwolnieni do domu. Zmusza ją tym samym do pozostania na wyspie i złożenia podziękowania za wielką łaskę uzdrowienia. W tej scenie Anatolij odsłania swoją ,zażyłość” z Bogiem, który odpowiada na jego pokorną prośbę i ingerując w ludzką rzeczywistość, zostawia w niej ślad swojej obecności.

W tych scenach Anatolij objawia naturę jurodiwego - świętego szaleńca wypełnionego Bożą obecnością, którego zadaniem jest „wytrącanie świata $z$ równowagi”. Jurodiwy przekracza granice, łączy ludzkie z boskim, znosi dychotomię świeckiego i świętego. Proces zachodzący w statycznej ikonie w jurodiwym spełnia się w jego dynamicznej cielesności. Żywoty jurodiwych sa absurdalna i desperacka próba ożywienia i ko ny Chrystusa. Swymi kształtami i barwami, własnymi siłami, pisza tę , ikonę" ${ }^{25}$. Jako widzialna ikona ludzka ukierunkowana na niewidzialne jurodiwy jest paradoksem świętości. Z jednej strony pokorny, żyjący w wyrzeczeniu i poniżeniu, z drugiej zuchwały, radykalnie ewangeliczny, prowokujący i konfrontujący. Jest powodem sprzeciwu i zgorszenia, ale jednocześnie zachwytu i adoracji. Tam, gdzie się pojawia, wystawia na próbę każdego, kto stara się żyć „na obraz i podobieństwo”. Jurodiwy to ludzki probierz zgodności z boskim paradygmatem. Bycie szaleńcem Bożym wymaga od człowieka pozostawienia wszystkiego, co świeckie i logiczne. Szaleniec Chrystusowy celowo wszystkich prowokuje swoim zachowaniem, które jest niedorzeczne, bezczelne i bezwstydne. A jednak saloita [obłąkaniec Chrystusowy, gr. salos: chwianie się] - mimo iż wydaje się głupcem tego świata - jest $w$ rzeczywistości wielkim prorokiem, któremu Bóg w nieokreślony sposób odkrywa swoje tajemnice ${ }^{26}$. Jurodiwy funkcjonuje zazwyczaj w konkretnej społeczności, przed którą ujawnia swoją gwałtowną i „rozchwianą" świętość. Jest dla niej znakiem Bożej inności i osobności. Swoim błazeńskim - w odczuciu otoczenia - postępowaniem wprowadza w obieg życia odkrywane przed nim Boże tajemnice. Jak każdy prorok, jest często odrzucony i wyśmiewany. Niezrozumienie i niezgoda na wiadomości przynoszone przez jurodiwego wpisują się w jego naśladownictwo Chrystusa.

„Prorokowanie” Anatolija przejawia się przede wszystkim w antycypacji przyszłych wydarzeń. Rzucone pod nogi Filareta nadpalone polano zapowiada pożar w monastyrze. W scenie samego pożaru zapytany o to Anatolij stwierdza, że jedynie Bóg zna czas zdarzeń i On sam decyduje o ich chronologii. W jednej z rozmów Anatolij tłumaczy się ze swojego przywiązania do pracy w kotłowni, mówiąc, że łatwiej się grzebie braci, kiedy ziemia jest niezmrożona. To zapowiedź pogrzebu, ale w filmie nie ma sceny pochówku. Trumna z Anatolijem odpływa łódką. Ujawnianie Bożych zamysłów jest jednocześnie ujawnianiem Bożej natury, której nie można doświadczyć inaczej niż w dynamice paradoksu i sprzeczności. Jurodiwy jedynie w pewnej mierze odsłania tajemnicę Boga. Boże działanie zostaje rozpoznane w ludzkim świecie, ale nigdy nie może być poznane do końca - tak jak ma to miejsce w scenie modlitwy o uzdrowienie i w scenie egzorcyzmu, w których działanie Bożej łaski staje się możliwe dzięki głębokiej wierze i wielkiej pokorze ,jurodiwego" Anatolija. Pod udawanym szaleństwem i teatralnością zachowań jurodiwy ukrywa tajemnicę tożsamości ukształtowanej nieustannym wpatrywaniem się w Boże oblicze i naśladowaniem Chrystusa w jego byciu blisko ludzi i w jego modlitewnym byciu blisko Boga. Jurodiwy nie ,zadomawia się” w świecie. Saloita jest (...) postacia wolna - wolną od więzów rodzinnych, od konwenansów, od wszelkich ograniczeń ${ }^{27}$. Ta wolność pozwala mu na ignorowanie przestrzennych i cza- 
sowych ram doczesności. Wie, że świat jest jedynie stanem przejściowym i czasem próby. Życie ziemskie dopełnia się dopiero w życiu wiecznym.

Cyprian Kamil Norwid, odnosząc się do powołania człowieka w kategoriach „obrazu i podobieństwa”, pisał przede wszystkim o powołaniu do życia kapłańskiego rozumianego jako służba Bogu. Jego koncepcja człowieka zakładała, że każdy jest zdolny do osiągnięcia pełni człowieczeństwa jako kapłan pozostający blisko Boga i inkarnujący w swoim życiu ,żywe bóstwo". Tak interpretował sens drogi ludzkiej, która swoje spełnienie znajduje w śmierci, ostatecznym sprawdzianie człowieczeństwa ${ }^{28}$. Po kapłańsku przeżyte życie gwarantuje chrześcijańskie odejście, zamknięcie całości żywota dojrzałego ${ }^{29}$. Żywot Anatolija zamyka przyjazd Tichona, który przybywa na wyspę w poszukiwaniu ratunku dla swojej chorej córki. Podróż Tichona pociągiem jest jedynym ,złamaniem” jedności miejsca wydarzeń. Scena w przedziale kolejowym daje wgląd w przestrzeń obopólnego cierpienia: ojca $-\mathrm{z}$ powodu stanu córki i córki $-\mathrm{z}$ powodu niezrozumienia natury dręczącej ją choroby. Egzorcyzm zaczyna się od gdaczącego Anatolija, który w ten sposób zwabia złego ducha. Zabiera opierającą się dziewczynę w miejsce swojego odosobnienia. Jest to przestrzeń szczególnie uświęcona, wypełniona samotnością i udręką psychiczną, ale przede wszystkim modlitwą, w której zawsze obecny jest Bóg. „Choreografia” sceny egzorcyzmu opiera się na kontraście ruchu i bezruchu. Anatolij klęczy niewzruszony przed Bogiem, prosząc Go o uwolnienie opętanej dziewczyny. Jego nieruchoma sylwetka stopiona z pustką i chłodem krajobrazu pozostaje w kontraście do wijącego się w konwulsjach ciała córki Tichona. Jej frenetyczne ruchy wskazują na działanie obcej siły. Przerażona dziewczyna próbuje uciekać i ukryć się. Anatolij zawierza Bogu jej życie i poddaje je działaniu Jego wszechmocy. Dziewczyna zostaje uwolniona od demona. Po wszystkim Anatolij obmywa jej twarz w wodzie - to gest kojarzący się z powtórnym chrztem i przyjęciem nowego życia.

Przyjazd Tichona na wsypę jest Bożą odpowiedzią na błagalne modlitwy Anatolija i jego „kapłańskie, jurodiwe” życie. Dzięki przebaczeniu Tichona Anatolij uzyskuje odpuszczenie swoich grzechów, „przyzwolenie” na odejście i spokój duszy. U mnie w duszy śpiewaja anioły - mówi Anatolij w scenie z Tichonem, który zapewnia go, że już dawno wszystko mu wybaczył i że może umierać w spokoju. Anatolij zadośćuczynił ludziom oraz Bogu i odpokutował swoją winę. Ocalony przez Tichona chce ocalić również jego. Próbuje go nakłonić do wejścia na drogę pojednania z Bogiem, ale Tichon odmawia, tłumacząc się niezrozumieniem propozycji. Ludzkie wybaczenie i obecność anielska w duszy Anatolija są zapowiedzią kończącego się ziemskiego pielgrzymowania. Rilke nazywa anioły interwałami w boskiej melodii: jeżeli świat, w jakim żyjemy, układa się (jeśli Bóg go ułożył) w jakiś zwiazek, w ciagłość jakiegoś tematu - to anioł (...) oznacza interwał, przerwę w tej ciagłości ${ }^{30}$. Ciągłość życia Anatolija zostaje zatem przerwana. Krzyczący w punkcie wyjścia: Żyję! w punkcie dojścia prosi szeptem: Panie, przyjmij moja grzeszną duszę.

\section{0}

Paweł Łungin w Wyspie pokazuje człowieka chodzącego po świecie w rytmie pracy i modlitwy. Film opowiada historię o popełnieniu grzechu ciężkiego i próbie jego odkupienia, która staje się jednocześnie pielgrzymką świętości, ta zaś rozpo- 
czyna się od winy (upadku), jest wypełniona pokutą, a kończy się przebaczeniem (zbawieniem). Między upadkiem a zbawieniem rozpięta jest droga każdego człowieka, który zdecyduje się ją skierować ku Bogu. Łungin traktuje film jako petnoprawny podmiot procesu refleksji ${ }^{31}$. Przygląda się człowiekowi nie tylko w kontekście religijnym, mimo że historia rozgrywa się w najbliższych mu realiach rosyjskiego prawosławia, ale również w kategoriach aksjologicznych. Ten filozoficzno-teologiczny traktat filmowy reżyser buduje z długich ujęć pokazujących pełny obraz życia człowieka i otaczającej go przestrzeni, a w planach bliskich ukazuje poszczególne aspekty jego bycia, intymny kontakt z Bogiem i relacje z ludźmi. Rzeczywistość wnętrza oddaje w modlitwach i dialogach, a rzeczywistość zewnętrza - w obrazie. Narracja opiera się na trzech wątkach: pracy, modlitwy i relacji międzyludzkich. Obrazy wożącego węgiel Anatolija przeplatają się ze scenami jego rozmów z Bogiem i spotkań z ludźmi. Rytm syzyfowej pracy i nieustannej modlitwy jest przerywany „seansami jurodstwa”. Narracyjną prostotę i wizualną czystość obrazu podkreśla dodatkowo jednolita kolorystyka. Dominujące szarości i chłodne błękity rozświetla czasami płomień ogniska w kotłowni i złoto ikonostasu w monastyrze.

Łungin konstruuje w Wyspie przestrzeń znaczeniową, gdzie każdy element jest powiązany z historią drogi duchowej głównego bohatera. Pojawiający się w scenie z przeszłości napis „Wojna” konotuje stan zabijania, którego naturalną konsekwencją jest popełnianie grzechów. Napis „Monastyr” w kolejnej scenie kojarzy się z obecnością sacrum i stanem uświęcenia. „Wojna” i „Monastyr” to zatem punkty demarkacyjne rozdzielające obszar grzeszności, po którym Anatolij poruszał się wcześniej, i obszar świętości, po którym porusza się obecnie. Jednocześnie „Wojna 1942” i „Monastyr 1976” wskazują na realny upływ czasu. Ponadtrzydziestoletni pobyt Anatolija na wyspie musiał być czasem wypełnionym pokutą i zmaganiem ze sobą. Reżyser nie pokazuje jednak radykalnej zmiany i całkowitego zwrotu ku Bogu, które stały się udziałem bohatera (przejście od grzeszności do świętości). W filmie oglądamy rezultaty tej zmiany. Łungin buduje dramaturgię w swoisty sposób: nie pokazuje bohatera w trakcie dokonywania wyborów, ale już zdeklarowanego, zakorzenionego w wyborze i pewnego obranego przez siebie kierunku. W scenie z przeszłości widać bierny podmiot, człowieka bezwolnego, niepanującego nad wydarzeniami. W pozostałych scenach działa podmiot czynny, aktywnie uczestniczący w otaczającej go rzeczywistości, świadomy swojego postępowania. Taki zabieg dramaturgiczny rodzi pytanie o to, w jaki sposób prosty palacz stał się człowiekiem świętym, cytującym ustępy z Biblii, modlącym się psalmami, przez którego działa łaska Boża, a zarazem pytanie o to, jak długą i dojmująco trudną drogę musiał przejść. Tajemnica tej zmiany ujawnia się w kolejnych scenach, w których pokazywane są jego zachowania, przekonania i wyznawane wartości, ale przede wszystkim jego szczególna ,święta” kondycja. Akcja filmu opiera się na stopniowym odsłanianiu tożsamości ontycznej bohatera - „wydarza się” w niej sam bohater. Treść życia Anatolija realizowanego w dynamice pielgrzymki pokutnej jest zarazem treścią fabuły. Zaczyna się w przeszłości od popełnionego grzechu, trwa w teraźniejszości w odbywanej pokucie i ma się zakończyć śmiercią w przyszłości. Czas jest tutaj okresem wyznaczonym na odprawienie pokuty i uzyskanie wybaczenia. Oczekiwanie bohatera na śmierć prowokuje kolejne pytanie o finał jego drogi. Napięcie rodzi się po części z pytań dotyczących bezpośrednio sytuacji 
głównego bohatera, a po części z namysłu nad topografią metafizycznego odniesienia człowieka, o której opowiada Łungin: do samego siebie, do świata poza nim i do Boga, który jest wszędzie.

Historia bohatera zostaje spięta paraboliczną klamrą. Łungin rozpoczyna film od ujęcia Anatolija płynącego łódką w miejsce odosobnienia, aby tam żałować za popełniony grzech i błagać Boga o wybaczenie; kończy również sceną z łódką, którą tym razem płynie trumna z jego ciałem. Droga bohatera zostaje tym samym metaforycznie podsumowana. Ubrany w białą szatę Anatolij kładzie się do przygotowanej uprzednio skrzyni. Ojciec Jow uderza w dzwony. Na ich dźwięk Anatolij zamyka oczy. Łódka z podtrzymywanym przez Jowa prawosławnym krzyżem płynie w nieznanym kierunku, w kadrze na chwilę pojawia się twarz ojca Filareta odprowadzającego wzrokiem kondukt pogrzebowy. Rozbielającemu się obrazowi towarzyszy żałobna pieśń chóru. Ostatnia scena jest symbolicznym przyjściem Boga, do którego Anatolij powraca. Ludzkie pielgrzymowanie jest zawsze relacyjne: człowiek idzie do Boga, a Bóg wychodzi naprzeciw człowiekowi.

Obraz łódki przypływającej na początku filmu i odpływającej z jego końcem pozwala spojrzeć na historię Anatolija jak na przypowieść o ludzkim życiu, które jest „,̇yciem w drodze”. W swojej międzyludzkiej, horyzontalnej perspektywie droga ta otwiera się jako wspólne, dzielone z innymi podobieństwo doświadczeń. W perspektywie wertykalnej, w odniesieniu do Absolutu, personalizuje się ona i nabiera indywidualnych właściwości. Wybór konkretnej drogi jest wyborem sposobu przeżywania swojego człowieczeństwa w topografii tych powiązań. Film stawia pytanie o drogę $\mathrm{w}$ jej najbardziej oczywistym przebiegu, w dramaturgii codziennych zdarzeń i teraźniejszości czasu, ale również w jej niecodziennym ruchu ku wieczności i Tajemnicy. Pojawia się w nim również pytanie o substancję, którą należy wypełnić ten odcinek między wydarzeniem narodzin a wydarzeniem śmierci. Zadane w filmie w kontekście teologicznym pytanie o drogę ludzką aktualizuje się równocześnie w kontekście filozoficznym. Namysł nad świętościa jest ostatecznie refleksja nad koncepcja człowieka ${ }^{32}$. Świętość ta jest interpretowana jako nieustanny ruch wykraczania poza rzeczywistość ograniczoną własną sytuacją egzystencjalną w świat Boga i w świat drugiego człowieka. A świat jest tym, po czym się chodzi. Gdy nie ma dokąd pójść, nie ma świata ${ }^{33}$.

KATARZYNA KOLMAN

${ }^{1}$ Pismo Święte Starego i Nowego Testamentu. Biblia Tysiąclecia - w przekładzie z języków oryginalnych, oprac. zespół biblistów polskich z inicjatywy Benedyktynów Tynieckich, wyd. 5., Wydawnictwo Pallottinum, Poznań 2007 (Rdz 3,9).

${ }^{2}$ Wilfrid Stinissen, teolog i filozof, łącząc oba podejścia metodologiczne, interpretuje sytuację grzechu pierworodnego przede wszystkim jako sytuację zerwanych relacji. Człowiek, zrywając kluczową dla jego jestestwa komunikację z Bogiem, z drugim człowiekiem i ze światem, działa w ten sposób przeciwko swojej ontologicznej integralności. Zob. W. Stinissen, Człowiek prawdziwy, thum. J. Iwaszkiewicz, Wydawnictwo „W drodze”, Poznań 2013, s. 105.

${ }^{3}$ C. Wodziński, Kairos, słowo/obraz terytoria, Gdańsk 2010, s. 7.

${ }^{4}$ Tamże, s. 58.

${ }^{5}$ M. Marczak, Teologia grzechu i świętości w ,Wyspie” Pawta Eungina, w: Kultura wizualna - teologia wizualna, red. W. Kawecki, J. S. Wojciechowski, D. Żukowska-Gardzińska, Instytut Papieża Jana Pawła II, Warszawa 2011, s. 205-206. 
${ }^{6}$ Cytat według ścieżki dźwiękowej filmu.

${ }^{7}$ A. Sanecka, Tradycja duchowa chrześcijaństwa wschodniego w filmie ,, Wyspa” Pawła Eungina, w: Perspektywa teologiczna w badaniach nad filmem, red. B. Wieczorek, Wydawnictwo „Scriptum”, Kraków 2018, s. 123.

${ }^{8}$ M. Marczak, dz. cyt., s. 200.

${ }^{9}$ A. Sanecka, dz. cyt., s. 114.

${ }^{10}$ B. Dąb-Kalinowska, Wstęp, w: tejże, Ikony, Wydawnictwo Bosz, Olszanica 2013, s. 7.

${ }^{11}$ P. Evdokimov, Życie duchowe w mieście, tłum. M. Żurowska, Wydawnictwo „W drodze”, Poznań 2011, s. 157.

${ }^{12}$ P. Śpiewak, Jom Kipur i Księga Jonasza, „Tygodnik Powszechny" 2019, nr 17-18, s. 24.

${ }^{13} \mathrm{~W}$ większości tradycji religijnych pielgrzymka dziękczynna, błagalna czy pokutna (w zależności od intencji pątnika) jest integralną częścią praktyki wiary. Pokonywanie drogi do miejsca świętego ma na celu realną zmianę sytuacji pielgrzymującego, wyproszenie potrzebnych łask, podziękowanie za te już otrzymane czy w końcu przebłaganie za popełnione zło. Jo Croissant zwraca uwagę, że w tradycji żydowskiej święte miasto Jeruzalem było celem wędrówki każdego pobożnego Żyda trzy razy do roku z okazji wielkich świąt. Pielgrzymujący Żydzi przychodzili do Jeruzalem nie $\mathrm{w}$ konkretnym celu, ale przede wszystkim po to, żeby widzieć Boga i żeby zostać przez Niego ujrzanym. Stawali przed Bożym obliczem i kierowali ku Niemu wzrok po to, żeby „wejść w siebie”. Pokonanie fizycznej trasy było niezbędne dla podjęcia drogi ,uwewnętrznienia" i dotarcia do Boga uobecniającego się w człowieku. Zob. J. Croissant, Ciało światynia piękna, tłum. R. Nehring, D. Adamski, Wydawnictwo „W drodze”, Poznań 2007, s. 50 .

14 Księga Psalmów; Psalm 51,12-13, thum. K. Markowki, O. M. Stolarczyk, Wydawnictwo Święty Wojciech, Poznań 2012, s. 92-93.

${ }^{15}$ Tamże.

${ }^{16}$ Zob. M. Buber, Droga człowieka wedtug nauczania chasydów, tłum. G. Zlatkes, Wydawnictwo Cyklady, Warszawa 2004, s. 51.
${ }^{17}$ Zob. C. Grabowski, Krzysztof Kieślowski’s Decaloque Series. The Problem of the Protagonists and Their Self-Transcedence, Maria Curie-Skłodowska University Press, Lublin 1997, s. 138.

${ }^{18}$ G. Ryś, Moc słowa, Wydawnictwo WAM, Kraków 2016, s. 275.

${ }^{19}$ P. Evdokimov, Duch Święty $w$ tradycji prawosławnej, thum. M. Żurowska, Wydawnictwo „W drodze”, Poznań 2012, s. 70.

${ }^{20}$ Zob. J. Tischner, Miłość nas rozumie. Rok liturgiczny z księdzem Tischnerem, Wydawnictwo Znak, Kraków 2011, s. 164.

${ }^{21}$ B. Forysiewicz, Katechizm (ojca) Anatolija, czyli czlowiek wobec sacrum, w: Sacrum w kinie dekade później, red. S. J. Konefał, M. Zelent, K. Kornacki, Wydawnictwo Uniwersytetu Gdańskiego, Gdańsk 2013, s. 165.

${ }^{22}$ Zob. G. Ryś, Wiara z lewej, prawej i bożej strony, Wydawnictwo WAM, Kraków 2016.

${ }^{23}$ Zob. P. Evdokimov, Życie duchowe... dz. cyt., s. 35 .

${ }^{24}$ M. Marczak, dz. cyt., s. 205.

${ }^{25}$ C. Wodziński, Św. Idiota, słowo/obraz terytoria, Gdańsk 2009, s. 226.

${ }^{26}$ A. Sanecka, dz. cyt., s. 127.

27 Tamże, s. 127.

${ }^{28}$ S. Sawicki, Sacrum w literaturze, w: tegoż, Poetyka. Interpretacja. Sacrum, Państwowe Wydawnictwo Naukowe, Warszawa 1981, s. 188 .

${ }^{29}$ Tamże.

${ }^{30} \mathrm{~K}$. Michalski, Eseje o Bogu i śmierci, Kurhaus Publishing, Warszawa 2014, s. 18.

31 A. Szpulak, Filmy Pawła Eungina „Car” $i$,Wyspa" wobec duchowej tradycji rosyjskiego prawostawia, w: Sacrum w kinie... dz. cyt., s. 149.

${ }^{32}$ H. Leleń, Parę uwag o kategorii świętości z perspektywy nauk humanistycznych. Rekonesans badawczy, w: Święci i świętość w języku, literaturze i kulturze, red. H. Leleń, T. Żurawlew, Universitas, Kraków 2018, s. 21.

${ }^{33}$ J. Tischner, dz. cyt., s. 172. 